Int. J. Electrochem. Sci., 14 (2019) 10966 - 10982

\title{
Corrosion Inhibition of a Sol-Gel Coating Modified with Cobalt- Enriched Zeolite on AA2024-T3 Aluminum Alloy
}

\author{
Bing Xue*, Xuemei Zong, Can Wang, Huayuan Zhang, Jing Luo \\ Jiangsu XCMG construction machinery research institute Ltd, 26\# Tuolanshan RD, Gulou District, \\ 221004, Xuzhou, Jiangsu, P.R.China. \\ *E-mail: xcmgxuebing@,163.com
}

doi: $10.20964 / 2019.12 .10$

Received: 11 July 2019 / Accepted: 29 August 2019 / Published: 29 October 2019

Cobalt-enriched zeolite ( $\mathrm{CoNaX}$ ) nanocontainers, synthesized by ion-exchange reactions of zeolite $\mathrm{X}$ $(\mathrm{NaX})$ and $\mathrm{Co}\left(\mathrm{NO}_{3}\right)_{2}$, were used as inhibitor additives to improve the corrosion protection of a sol-gel coating. A dispersion of CoNaX zeolite was uniform in the sol-gel coating and caused no defects. An increase in coating thickness was unapparent with the addition of CoNaX zeolite. Results of tests indicated that the corrosion protective properties of the sol-gel coating were remarkably improved. This was attributed to an enhanced cross-linking density by zeolite particles and a controlled release of $\mathrm{Co}^{2+}$ in $\mathrm{CoNaX}$ zeolite. The released $\mathrm{Co}^{2+}$ reacted with $\mathrm{OH}^{-}$from corrosion products, which formed a $\mathrm{Co}$ oxide/hydroxide precipitation. The precipitation covered defects and prevented contact of electrolyte with the substrate, which further slowed corrosion processes. CoNaX zeolite provided the coating with long-term inhibitive properties.

Keywords: zeolite; corrosion inhibitor; ion-exchange; sol-gel coating; electrochemistry

\section{$\underline{\text { FULL TEXT }}$}

(C) 2019 The Authors. Published by ESG (www.electrochemsci.org). This article is an open access article distributed under the terms and conditions of the Creative Commons Attribution license (http://creativecommons.org/licenses/by/4.0/). 